\title{
An 800-year long, radiocarbon-dated varve chronology from south-eastern Sweden
}

\author{
BARBARA WOHLFARTH, SVANTE BJÖRCK, GÖRAN POSSNERT AND BJÖRN HOLMQUIST
}

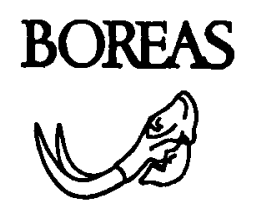

\begin{abstract}
Wohlfarth, B., Björck, S., Possnert. G. \& Holmquist, B. 1998 (December): An 800-year long. radiocarbondated varve chronology from south-eastern Sweden. Boreas, Vol. 27, pp. 243-257. Oslo. ISSN 0300-9483.

More than 50 varve-thickness diagrams, which were established from glacial varved clays in south-eastern Sweden were correlated with each other to form an 800-year long floating varve chronology. AMS ${ }^{14} \mathrm{C}$ measurements on terrestrial macrofossils from the varved clays enabled synchronization of the record with other high-resolution archives. The synchronization indicates that the chronology spans between $c .13150$ and c. 12350 calendar years BP and covers the later part of the Allered and the early part of the Younger Dryas. Calibrated radiocarbon dates, which were obtained on varved clays south of the floating chronology, indicate that the ice recession in south-eastern Sweden may have started during late Bølling. Our results indicate a longer time-span in varve years for the deglaciation than has been previously estimated.

Barbara Wohlfarth, Department of Quaternary Geology, University of Lund, Tornavägen 13, S-22363 Lund, Sweden: Göran Possnert, Tandem Laboratory, Box 533, S-75121 Uppsala, Sweden; Svante Björck. Geological Institute, University of Copenhagen, Oster Voldgade 10. DK-1350 Copenhagen K, Denmark; Björn Holmquist, Department of Mathematical Statistics, Lund University, Box 118, 22100 Lund, Sweden; received IOth March 1998. accepted 18th September 1998
\end{abstract}

Glacial varved clays with their characteristic silty summer and clayey winter layers underlie lacustrine deposits in many areas along the Baltic coast and in the Baltic Sea. These rhythmites, which were deposited during the retreat of the Fennoscandian ice sheet, are interpreted to reflect seasonal variations in sediment input into the Baltic basin (De Geer 1912). By constructing varve-thickness diagrams in open sections and by successively correlating these from south to north, De Geer was able to establish a varve chronology along the Swedish east coast. His chronology represented the first attempt to estimate the timing of the ice recession. Since then, the Swedish varve chronology or 'Swedish Time Scale' has been continuously revised and connected to present time (Cato 1987; Björck et al. 1992).

As part of a project designed to test the suitability of the glacial varves as a radiocarbon calibration tool, clay-varve localities were cored in south-eastern Sweden between AD 1991 and AD 1995 (Fig. 1) and analysed for datable terrestrial plant macrofossils (Wohlfarth et al. 1993). Although some of the results have been presented earlier (Wohlfarth et al. 1995), varve-thickness diagrams and their correlations have so far only been published for southernmost Sweden (Wohlfarth et al. 1994). Here, we present varve diagrams from south-eastern Sweden, their cross-correlation and the corresponding AMS ${ }^{14} \mathrm{C}$ measurements on terrestrial plant macrofossils. Owing to the uncertainties inherent in the Swedish Time Scale (see Björck et al. 1996; Wohlfarth 1996; Wohlfarth et al. 1997), this new chronology cannot be linked to a calendaryear time scale. To circumvent these problems, we have matched the data set to other high-resolution records through the distinct radiocarbon changes, which occurred over the Allerød-Younger Dryas boundary (Goslar et al. 1995; Björck et al. 1996; Goslar et al. 1999).

\section{The local varve chronology in south-eastern Sweden}

Varve chronological investigations in south-eastern Sweden (Fig. 1B) were carried out earlier by a number of researchers (see Kristiansson (1986) for a review). Kristiansson (1986) compiled these unpublished and published diagrams and presented, together with new clay-varve diagrams, a revised chronology. Kristiansson chose an independent time scale, which was not connected to any of the earlier established chronologies. His local, floating, chronology is based on sites in a $\mathrm{N}-\mathrm{S}$ - and a NW-SE-oriented valley (Fig. $1 \mathrm{~b})$. It consists of 107 varve diagrams and comprises a total of 2310 varve years. The investigation of individual sites and a careful evaluation of their topographic position made it possible to reconstruct the timing of the ice recession in local varve years. Kristiansson estimated that the deglaciation between his southernmost site (Högsby) and the northernmost site (Norrköping) took place over $c .1600$ varve years (Fig. 1B).

Based on lithological criteria, the occurrence of disturbances and the decrease in the rate of the ice recession, Kristiansson (1986) placed the Allerød/ Younger Dryas boundary at about the local varve year 1760 . In contrast to earlier investigations (see e.g. the summaries in Agrell et al. (1976) and Berglund (1979), where an ice-marginal zone with an ice re-advance had been observed in the area around Vimmerby (Fig. 1B), Kristiansson argued for a continuous 


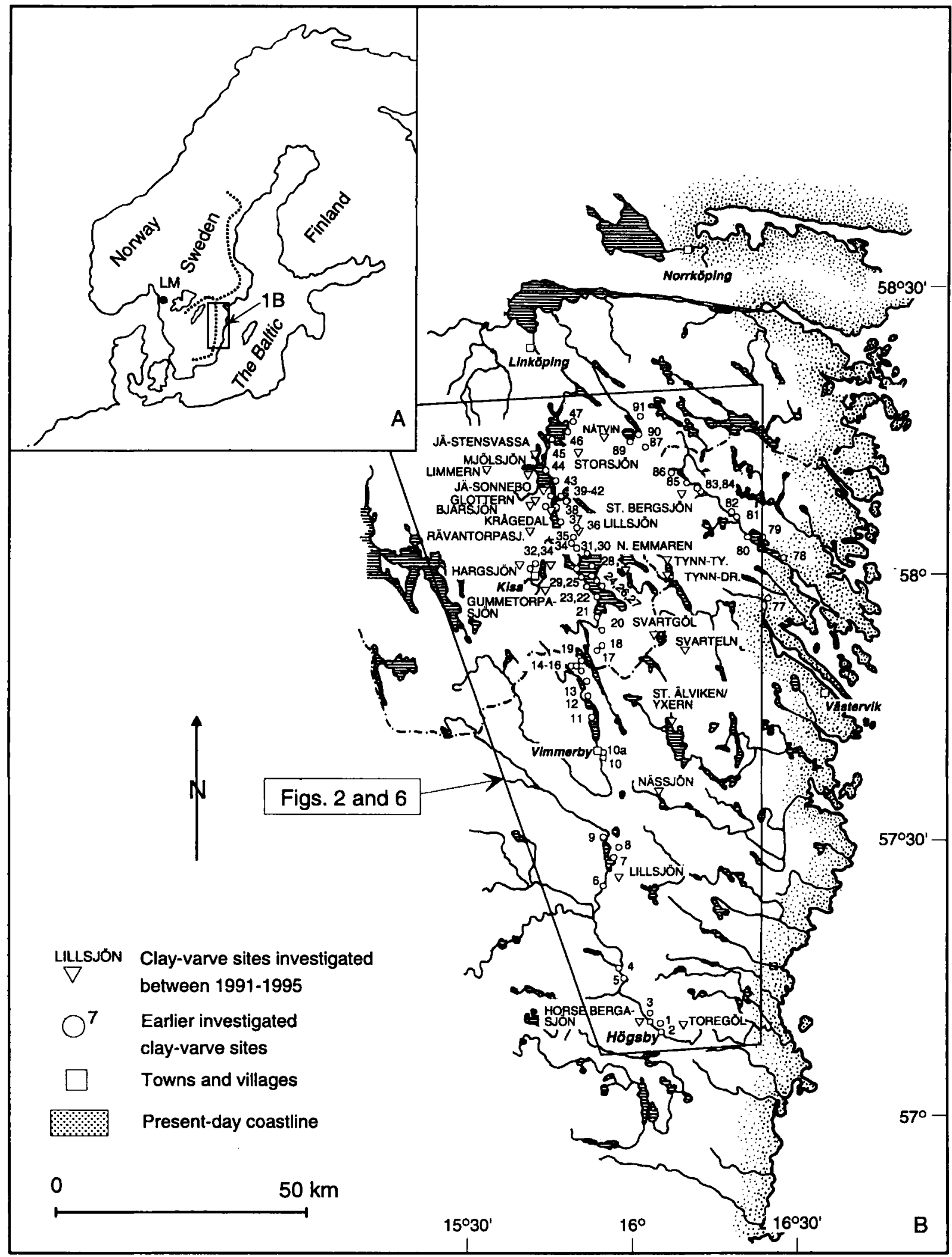

Fig. I. $\square$ A. Location of the study area in SE Sweden and the extension of the Swedish varve chronology along the Swedish east coast (dotted line). LM = Lake Madtjärn. $\square$ B. Location of the varved-clay sites which were investigated between $1991-1995$ (open triangles), and of those published by Kristiansson (1986) (open circles) in south-eastern Sweden (the youngest sites, 48-75 are not shown). The numbering of Kristiansson's sites follows Holmquist \& Wohlfarth (1998), see also Table 2. 
ice recession up to the 'Middle Swedish Endmoraine Zone'.

A tentative correlation between the local varve chronologies in south-eastern and southernmost Sweden (Ringberg 1991) was attempted by Björck \& Möller (1987). They linked the thin varves, which were deposited in southernmost Sweden during the Older Dryas pollen zone, to the thin varves, which are characteristic of the area around Högsby between the local varve years $2700-2560$ in Kristiansson's time scale (Fig. 1B). The deposition of fairly thick varves, which occurred more or less synchronously around the local varve year $2560 / 2550$ and which coincides with the deglaciation of Vimmerby was attributed to the beginning of the Allerød. Brunnberg (1995) recently connected Kristiansson's chronology to the main part of the Swedish Time Scale. This was done by synchronizing the marked colour change, which is visible in Brunnberg's clay varves around the varve years 10712 $10726 \mathrm{BP}$ and in Kristiansson's chronology at the local varve year 707/708. This colour change is also seen in varved clays further to the west (Strömberg 1994). It is thought to reflect the second drainage of the Baltic Ice Lake and coincides approximately with the Younger Dryas/Preboreal transition (Strömberg 1994). The correlation between Brunnberg's (1995) and Kristiansson's chronologies was used to extend the whole Swedish varve chronology back to about 12830 varve years BP (corresponding to the local varve year 2825). The above outlined correlations lead to an age of $c .12570$ varve years BP and c. 11770 varve years BP for the Older Dryas/Allerød and Allerød/Younger Dryas transitions, respectively. This would imply a length of $c .800$ varve years for the Allerød period and of $c .1050$ years for the Younger Dryas.

The varve diagrams published by Kristiansson were all digitized during the course of the current investigation and numbered from 1 to 91 . Based on this data set, cross-correlation analyses were performed, which showed that out of 191 analysed diagram connections, only $15 \%$ indicate a significant correlation at the published link (Holmquist \& Wohlfarth 1998). In most cases statistically invalid correlations were observed and alternative placements were possible, which shows that the visual correlations in Kristiansson's chronology are weak and only partly fulfil the requirements for statistically valid varve diagram correlations (Holmquist \& Wohlfarth 1998).

\section{Site selection and methods}

\section{Site selection}

The aim of our investigation was to core varved-clay sites situated near to those sites upon which Kristiansson's diagrams were established and also where varved clays were deposited close to the former highest shoreline of the Baltic Ice Lake. It was expected that the new diagrams would be easy to correlate to Kristiansson's diagrams and the in-wash of organic material should have been sufficient for ${ }^{14} \mathrm{C}$ dating in areas close to the former coast and narrow fjords (Wohlfarth et al. 1994) (Fig. 2).

Estimations of the altitude of the highest shoreline are given by Kristiansson, who compiled these data from various sources. The highest shoreline, which is characterized by, for example, delta deposits and washed boulder surfaces, is metachronous over the whole area (Agrell 1976). It developed during the deglaciation as a combined effect of isostatic land-uplift and damming of the Baltic Ice Lake prior to its final drainage (Björck 1995).

The investigated localities are now situated between c. 25 and $100 \mathrm{~km}$ from the present coast of the Baltic Sea (Fig. 1B). However, during the deglaciation, the

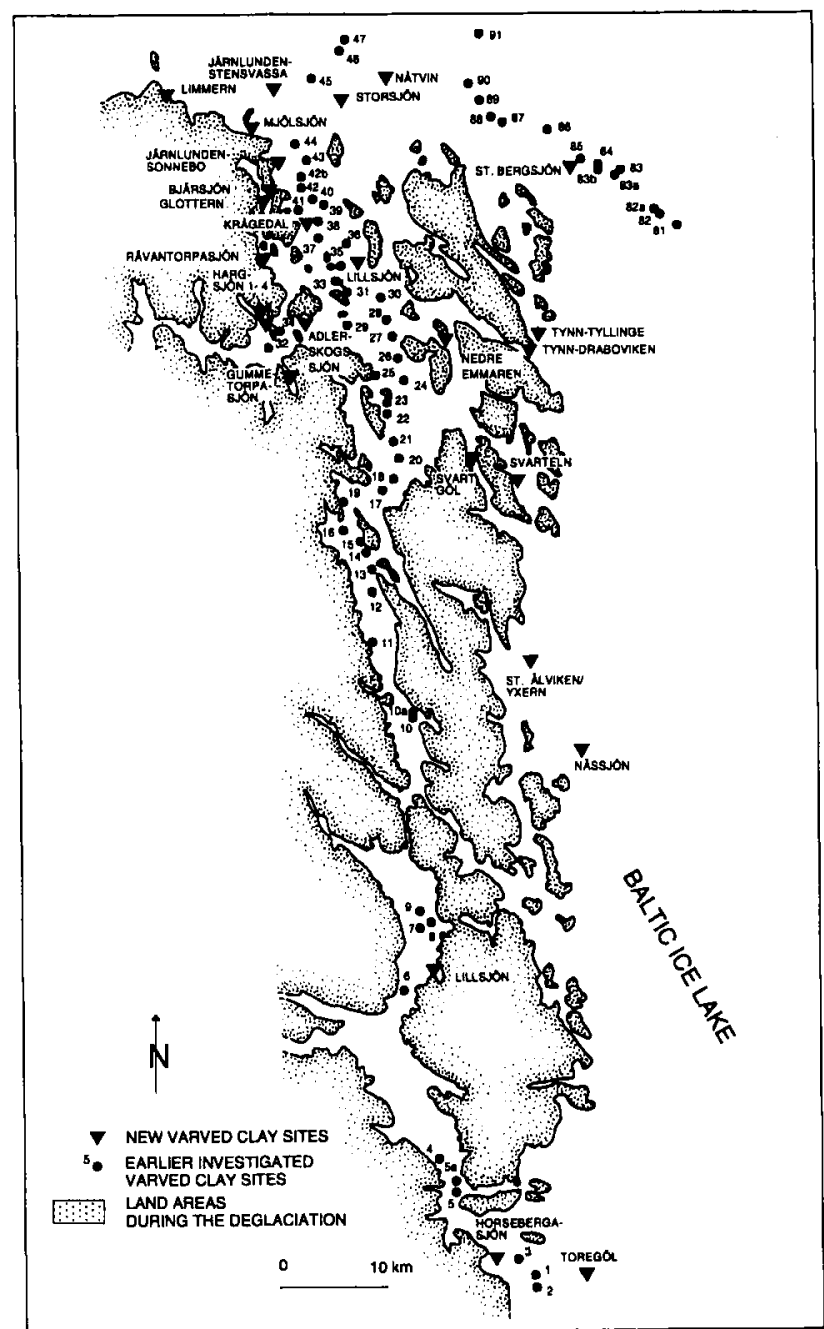

Fig. 2. The location of the investigated clay-varve sites (filled triangles) and Kristiansson's (1986) sites (filled circles) in relation to the highest coastline of the Baltic Ice Lake. See Fig. IB for the geographical position of this map. 
Table I. Varved-clay sites investigated in the provinces of Småland and Östergötland between the years 1991 and 1995 . $+=$ bottom varve has not been reached, $>=$ more varves follow below a disturbance. The varve thickness diagrams shown in Fig. 5A-C are marked with an asterisk. See Figs 3 and 4 for their location. The calendar-year of the bottom varves was estimated by synchronizing the data set to Gosciaz (see text).

\begin{tabular}{|c|c|c|c|c|c|c|}
\hline Site name & $\begin{array}{l}\text { Province/ } \\
\text { map sheet }\end{array}$ & Coordinates & $\begin{array}{l}\text { Height } \\
\text { a. s. } 1 \text {. }\end{array}$ & $\begin{array}{l}\text { No. of } \\
\text { varves }\end{array}$ & $\begin{array}{l}\text { Age of bottom } \\
\text { varve (local vy) }\end{array}$ & $\begin{array}{l}\text { Age of bottom varve } \\
\text { in calendar years BP }\end{array}$ \\
\hline Toregöl 1 & $\begin{array}{l}\text { Småland } \\
5 \mathrm{G} \text { NV }\end{array}$ & $\begin{array}{l}\mathrm{N} 57^{\circ} 90^{\prime} 03^{\prime \prime} \\
\mathrm{E} 16^{\circ} 07^{\prime} 12^{\prime \prime}\end{array}$ & c. $80 \mathrm{~m}$ & 169 & Not possible to connect & \\
\hline Toregöl 2 & $\begin{array}{l}\text { Småland } \\
5 \mathrm{G} \mathrm{NV}\end{array}$ & $\begin{array}{l}N 57^{\circ} 09^{\prime} 03^{\prime \prime} \\
\mathrm{E} 16^{\circ} 07^{\prime} 12^{\prime \prime}\end{array}$ & c. $80 \mathrm{~m}$ & 129 & Not possible to connect & \\
\hline Horsebergasjön 1 - & $\begin{array}{l}\text { Smảland } \\
5 \mathrm{G} \mathrm{NV}\end{array}$ & $\begin{array}{l}\mathrm{N} 57^{\circ} 09^{\prime} 39^{\prime \prime} \\
\mathrm{E} 15^{\circ} 59^{\prime} 00^{\prime \prime}\end{array}$ & $84.6 \mathrm{~m}$ & 218 & Not possible to connect & \\
\hline Horsebergasjön 1 & $\begin{array}{l}\text { Småland } \\
5 G \mathrm{NV}\end{array}$ & $\begin{array}{l}\mathrm{N} 57^{\circ} 09^{\prime} 39^{\prime \prime} \\
\mathrm{E}^{\circ} 5^{\circ} 59^{\prime} 00^{\prime \prime}\end{array}$ & $84.6 \mathrm{~m}$ & 176 & Not possible to connect & \\
\hline Lillsjön/Hagelsrum 1 & $\begin{array}{l}\text { N Småland } \\
6 \mathrm{G} \mathrm{SV}\end{array}$ & $\begin{array}{l}\mathrm{N} 57^{\circ} 25^{\prime} 21^{\prime \prime} \\
\mathrm{E} 15^{\circ} 54^{\prime} 27^{\prime \prime}\end{array}$ & $96.8 \mathrm{~m}$ & $128+>240$ & Not possible to connect & \\
\hline Lillsjön/Hagelsrum 2 & $\begin{array}{l}\text { N Småland } \\
6 \mathrm{G} \mathrm{SV}\end{array}$ & $\begin{array}{l}N 57^{\circ} 25^{\prime} 21^{\prime \prime} \\
\text { E1 } 5^{\circ} 54^{\prime} 27^{\prime \prime}\end{array}$ & $96.8 \mathrm{~m}$ & $134+>460$ & Not possible to connect & \\
\hline Lillsjön/Hagelsrum 3 & $\begin{array}{l}\text { N Småland } \\
\text { 6G SV }\end{array}$ & $\begin{array}{l}\mathrm{N} 57^{\circ} 25^{\prime} 21^{\prime \prime} \\
\mathrm{E} 15^{\circ} 54^{\prime} 27^{\prime \prime}\end{array}$ & $96.8 \mathrm{~m}$ & 133 & Not possible to connect & \\
\hline Nässjön & $\begin{array}{l}\text { N Småland } \\
6 \mathrm{G} \mathrm{NV}\end{array}$ & $\begin{array}{l}\text { N55 } 57^{\circ} 37^{\prime} 28^{\prime \prime} \\
\text { E16 } 6^{\circ} 11^{\prime} 36^{\prime \prime}\end{array}$ & $66.3 \mathrm{~m}$ & $64+>100$ & Not possible to connect & \\
\hline Yxern/St. Älviken & $\begin{array}{l}\text { N Småland } \\
6 G \text { NV }\end{array}$ & $\begin{array}{l}\mathrm{N} 57^{\circ} 42^{\prime} 40^{\prime \prime} \\
\mathrm{E} 16^{\circ} 04^{\prime} 08^{\prime \prime}\end{array}$ & $\begin{array}{l}90.7 \\
-92.6 \mathrm{~m}\end{array}$ & 236 & Not possible to connect & \\
\hline Svarteln & $\begin{array}{l}\text { N Småland } \\
7 \mathrm{G} \mathrm{SV}\end{array}$ & $\begin{array}{l}N 57^{\circ} 51^{\prime} 33^{\prime \prime} \\
\text { E16 } 07^{\prime} 37^{\prime \prime}\end{array}$ & $96.7 \mathrm{~m}$ & 266 & Not possible to connect & \\
\hline Svartgöl/Spillen & Östergötland & $\mathrm{N} 57^{\circ} 52^{\prime} 15^{\prime \prime}$ & $115 \mathrm{~m}$ & c. 270 & Not possible to connect & \\
\hline Tynn/Draboviken* & $\begin{array}{l}\text { Småland } \\
7 \mathrm{G} \mathrm{NV}\end{array}$ & $\begin{array}{l}\mathrm{N} 57^{\circ} 58^{\prime} 54^{\prime \prime} \\
\mathrm{E} 16^{\circ} 04^{\prime} 02^{\prime \prime}\end{array}$ & $\begin{array}{l}85.1- \\
86.2 \mathrm{~m}\end{array}$ & 189 & $2278+$ & $12928+$ \\
\hline Tynn/Tyllinge* & $\begin{array}{l}\text { Småland } \\
7 \mathrm{G} \mathrm{NV}\end{array}$ & $\begin{array}{l}\mathrm{N} 58^{\circ} 00^{\prime} 30^{\prime \prime} \\
\mathrm{E} 16^{\circ} 05^{\prime} 15^{\prime \prime}\end{array}$ & $85.1-$ & 262 & 2358 & 13008 \\
\hline Nedre Emmaren* & $\begin{array}{l}\text { Östergötland } \\
7 \mathrm{G} \mathrm{NV}\end{array}$ & $\begin{array}{l}\text { N } 57^{\circ} 59^{\prime} 15^{\prime \prime} \\
\text { E } 15^{\circ} 56^{\prime} 30^{\prime \prime}\end{array}$ & $104 \mathrm{~m}$ & 268 & 2314 & 12964 \\
\hline Gummetorpasjön l* & $\begin{array}{l}\text { Östergötland } \\
\text { 7F NO }\end{array}$ & $\begin{array}{l}\text { N } 57^{\circ} 57^{\prime} 40^{\prime \prime} \\
\text { E15 } 39^{\prime} 45^{\prime \prime}\end{array}$ & $116 \mathrm{~m}$ & 327 & 2231 & 12881 \\
\hline Gummetorpasjön 2 & $\begin{array}{l}\text { Östergötland } \\
\text { 7F NO }\end{array}$ & $\begin{array}{l}\mathrm{N} 57^{\circ} 57^{\prime} 40^{\prime \prime} \\
\mathrm{E} 15^{\circ} 39^{\prime} 45^{\prime \prime}\end{array}$ & $116 \mathrm{~m}$ & 268 & $2190+$ & $12840+$ \\
\hline Adlerskogsjön 1 & $\begin{array}{l}\text { Östergötland } \\
\text { 7F NO }\end{array}$ & $\begin{array}{l}\mathrm{N} 58^{\circ} 00^{\prime} 16^{\prime \prime} \\
\mathrm{E} 15^{\circ} 40^{\prime} 45^{\prime \prime}\end{array}$ & $99 \mathrm{~m}$ & 207 & 2168 & 12818 \\
\hline Adlerskogsjön $2^{*}$ & $\begin{array}{l}\text { Östergötland } \\
7 \mathrm{~F} \mathrm{NO}\end{array}$ & $\begin{array}{l}\mathrm{N} 58^{\circ} 00^{\prime} 16^{\prime \prime} \\
\mathrm{E} 15^{\circ} 40^{\prime} 45^{\prime \prime}\end{array}$ & $99 \mathrm{~m}$ & 246 & 2183 & 12883 \\
\hline Hargsjön 1 & $\begin{array}{l}\text { Östergötland } \\
\text { 7F NO }\end{array}$ & $\begin{array}{l}\mathrm{N} 58^{\circ} 00^{\prime} 11^{\prime \prime} \\
\mathrm{E} 15^{\circ} 36^{\prime} 5 \mathrm{I}^{\prime \prime}\end{array}$ & $115.4 \mathrm{~m}$ & 223 & $2125+$ & $12775+$ \\
\hline Hargsjön 2 & $\begin{array}{l}\text { Östergötland } \\
\text { 7F NO }\end{array}$ & $\begin{array}{l}\mathrm{N} 58^{\circ} 00^{\prime} 57^{\prime \prime} \\
\mathrm{E} 15^{\circ} 36^{\prime} 51^{\prime \prime}\end{array}$ & $115.4 \mathrm{~m}$ & 149 & $2055+$ & $12705+$ \\
\hline Hargsjön 3 & $\begin{array}{l}\text { Östergötland } \\
\text { 7F NO }\end{array}$ & $\begin{array}{l}\text { N5 } 58^{\circ} 00^{\prime} 57^{\prime \prime} \\
\text { E15 } 15^{\circ} 36^{\prime} 51^{\prime \prime}\end{array}$ & $115.4 \mathrm{~m}$ & 124 & $2043+$ & $12693+$ \\
\hline Hargsjön $4^{*}$ & $\begin{array}{l}\text { Östergötland } \\
7 \mathrm{~F} \mathrm{NO}\end{array}$ & $\begin{array}{l}\text { N58 } 08^{\circ} 57^{\prime \prime} \\
\text { E15 } 36^{\prime} 51^{\prime \prime}\end{array}$ & $115.4 \mathrm{~m}$ & 218 & 2153 & 12803 \\
\hline Lillsjön* & $\begin{array}{l}\text { Östergötland } \\
7 \mathrm{~F} \mathrm{NO}\end{array}$ & $\begin{array}{l}\mathrm{N} 58^{\circ} 03^{\prime} 55^{\prime \prime} \\
\mathrm{E} 15^{\circ} 46^{\prime} 45^{\prime \prime}\end{array}$ & $85.3 \mathrm{~m}$ & 156 & Not nossible to connect & $12799+$ \\
\hline St. Bergsjön & $\begin{array}{l}\text { Östergötland } \\
7 \mathrm{G} \mathrm{NV}\end{array}$ & $\begin{array}{l}\mathrm{N} 58^{\circ} 08^{\prime} 20^{\prime \prime} \\
\mathrm{E} 16^{\circ} 09^{\prime} 33^{\prime \prime}\end{array}$ & $78.2 \mathrm{~m}$ & 255 & Not possible to connect & \\
\hline Rävantorpasjön* & $\begin{array}{l}\text { Östergötland } \\
7 \mathrm{~F} \mathrm{NO}\end{array}$ & $\begin{array}{l}\mathrm{N} 58^{\circ} 04^{\prime} 00^{\prime \prime} \\
\mathrm{E} 15^{\circ} 40^{\prime} 00^{\prime \prime}\end{array}$ & $116 \mathrm{~m}$ & 130 & 2082 & 12732 \\
\hline Åsunden/Krågedal* & $\begin{array}{l}\text { Östergötland } \\
7 \mathrm{~F} \mathrm{NO}\end{array}$ & $\begin{array}{l}\mathrm{N} 58^{\circ} 06^{\prime} 15^{\prime \prime} \\
\mathrm{E} 15^{\circ} 41^{\prime} 15^{\prime \prime}\end{array}$ & $86.2 \mathrm{~m}$ & 163 & 2057 & 12707 \\
\hline Glottern 1 & $\begin{array}{l}\text { Östergötland } \\
\text { 7F NO }\end{array}$ & $\begin{array}{l}\text { N58 } 08^{\circ} 07^{\prime} 20^{\prime \prime} \\
\text { E1 } 15^{\circ} 37^{\prime} 15^{\prime \prime}\end{array}$ & $111 \mathrm{~m}$ & 159 & $1995+$ & $12645+$ \\
\hline Glottern $2^{*}$ & $\begin{array}{l}\text { Östergötland } \\
7 \mathrm{~F} \text { NO }\end{array}$ & $\begin{array}{l}\mathrm{N} 58^{\circ} 07^{\prime} 20^{\prime \prime} \\
\mathrm{E} 15^{\circ} 37^{\prime} 15^{\prime \prime}\end{array}$ & $111 \mathrm{~m}$ & 198 & 2003 & 12653 \\
\hline Glottern 3 & $\begin{array}{l}\text { Östergötland } \\
\text { 7F NO }\end{array}$ & $\begin{array}{l}\mathrm{N} 58^{\circ} 07^{\prime} 20^{\prime \prime} \\
\mathrm{E} 15^{\circ} 37^{\prime} 15^{\prime \prime}\end{array}$ & $111 \mathrm{~m}$ & 150 & $1954+$ & $12604+$ \\
\hline Bjärsjön* & $\begin{array}{l}\text { Östergötland } \\
7 F \text { NO }\end{array}$ & $\begin{array}{l}\text { N } 58^{\circ} 07^{\prime} 45^{\prime \prime} \\
\text { E1 } 5^{\circ} 38^{\prime} 15^{\prime \prime}\end{array}$ & $110.2 \mathrm{~m}$ & 75 & 1983 & 12633 \\
\hline $\begin{array}{l}\text { Järnlunden/ } \\
\text { Sonebo* }\end{array}$ & Östergötland & $\mathrm{N} 58^{\circ} 09^{\prime} 25^{\prime \prime}$ & $86.2 \mathrm{~m}$ & 93 & $1890+$ & $12540+$ \\
\hline
\end{tabular}


Table 1 . Continued.

\begin{tabular}{|c|c|c|c|c|c|c|}
\hline Site name & $\begin{array}{l}\text { Province/ } \\
\text { map sheet }\end{array}$ & Coordinates & $\begin{array}{l}\text { Height } \\
\text { a. s. } 1 .\end{array}$ & $\begin{array}{l}\text { No. of } \\
\text { varves }\end{array}$ & $\begin{array}{l}\text { Age of bottom } \\
\text { varve (local vy) }\end{array}$ & $\begin{array}{l}\text { Age of bottom varve } \\
\text { in calendar years BP }\end{array}$ \\
\hline Mjölsjön 1* & $\begin{array}{l}\text { 7F NO } \\
\text { Östergötland } \\
8 \mathrm{~F} \mathrm{SO}\end{array}$ & $\begin{array}{l}\text { E1 } 5^{\circ} 38^{\prime} 30^{\prime \prime} \\
\text { N58 } 58^{\circ} 10^{\prime} 15^{\prime \prime} \\
\text { E1 } 5^{\circ} 36^{\prime} 35^{\prime \prime}\end{array}$ & $120 \mathrm{~m}$ & 155 & 1905 & 12555 \\
\hline Mjölsjön 2 & $\begin{array}{l}\text { Östergötland } \\
8 \mathrm{~F} \mathrm{SO}\end{array}$ & $\begin{array}{l}\text { N5 } 58^{\circ} 10^{\prime} 15^{\prime \prime} \\
\text { E15 } 36^{\circ} 35^{\prime \prime}\end{array}$ & $120 \mathrm{~m}$ & 154 & 1901 & 12551 \\
\hline Limmern* & $\begin{array}{l}\text { Östergötland } \\
8 \mathrm{~F} \mathrm{SO}\end{array}$ & $\begin{array}{l}\text { N58 } 58^{\circ} 12^{\prime} 45^{\prime \prime} \\
\text { E1 } 5^{\circ} 30^{\prime} 15^{\prime \prime}\end{array}$ & $115.2 \mathrm{~m}$ & 171 & 1871 & 12521 \\
\hline $\begin{array}{l}\text { Järnlunden/ } \\
\text { Stensvassa* }\end{array}$ & $\begin{array}{l}\text { Östergötland } \\
8 \mathrm{~F} \mathrm{SO}\end{array}$ & $\begin{array}{l}\text { N } 58^{\circ} 13^{\prime} 16^{\prime \prime} \\
\text { E } 14^{\circ} 38^{\prime} 30^{\prime \prime}\end{array}$ & $86.2 \mathrm{~m}$ & 135 & $1868+$ & $12518+$ \\
\hline Nåtvin* & $\begin{array}{l}\text { Östergötland } \\
8 \mathrm{G} \mathrm{SV}\end{array}$ & $\begin{array}{l}N 58^{\circ} 14^{\prime} 29^{\prime \prime} \\
\text { E1 } 5^{\circ} 51^{\prime} 00^{\prime \prime}\end{array}$ & $94 \mathrm{~m}$ & 142 & 1909 & 12559 \\
\hline Storsjöñ & $\begin{array}{l}\text { Östergötland } \\
8 \mathrm{~F} \mathrm{SO}\end{array}$ & $\begin{array}{l}N 58^{\circ} 12^{\prime} 16^{\prime \prime} \\
\text { E1 } 15^{\circ} 45^{\prime} 00^{\prime \prime}\end{array}$ & $105 \mathrm{~m}$ & 157 & 1900 & 12550 \\
\hline
\end{tabular}

palaeogeography of the area was markedly different (Fig. 2). The dammed Baltic Ice Lake expanded far to the west and the now-uplifted region was composed of an archipelago with deeply incised, narrow fjords and numerous islands, where glaciolacustrine varved clays were deposited. Owing to the metachronous develop- ment of the highest shoreline, the former coastline close to the southernmost sites investigated here (Toregöl, Horsebergasjön) is situated at about $96 \mathrm{~m}$ a.s.l. and reaches about $140 \mathrm{~m}$ a. s. 1 . close to Limmern (Agrell 1976) (Fig. 2). The gradual land-uplift caused a successive shallowing of the newly deglaci-

Table 2. Original and revised local varve age for the bottom varves in diagrams published by Kristiansson (1986) for northern Småland and southern Östergötland. $+=$ bottom varve has not been reached. See Figs. 3 and 4 for the location of the sites and Figs. 5A-C for varve-thickness diagrams. Sites $1-13,15,19,34,44$, and $77-91$ could not be correlated to the new chronology. The calendar-year age of the bottom varves is an estimate based on a synchronization of the data set to Gosciaz (see text).

\begin{tabular}{|c|c|c|c|c|}
\hline $\begin{array}{l}\text { Site } \\
\text { no. }\end{array}$ & Locality & $\begin{array}{l}\text { Original bottom } \\
\text { varve age in } \\
\text { local varve years }\end{array}$ & $\begin{array}{l}\text { Revised age of the } \\
\text { bottom varve }\end{array}$ & $\begin{array}{l}\text { Age of bottom } \\
\text { varve } \\
\text { in calendar years BP }\end{array}$ \\
\hline 14 & Kåreda & 2432 & 2475 & 13125 \\
\hline 16 & Järpekullen & 2408 & 2450 & 13100 \\
\hline 17 & Brunebo & 2403 & 2446 & 13086 \\
\hline 18 & Dråpetorp & 2393 & 2436 & 13076 \\
\hline 21 & Aby & 2339 & 2382 & 13023 \\
\hline 22 & Greby & 2321 & 2364 & 13014 \\
\hline 23 & Kristineberg & 2308 & 2351 & 13001 \\
\hline 24 & Gumhem & $2222+22$ & $2266+22$ & 12938 \\
\hline 25 & Långebro & 2271 & 2314 & 12964 \\
\hline 26 & Lövdalen & 2263 & 2306 & 12956 \\
\hline 27 & Kärra & 2240 & 2283 & 12933 \\
\hline 28 & Bjuggö & 2215 & 2258 & 12908 \\
\hline 30 & Stjärnevik & 2183 & 2227 & 12877 \\
\hline 31 & Årteryd & 2165 & 2209 & 12859 \\
\hline 32 & Kisa & 2132 & 2188 & 12838 \\
\hline 33 & Boda & 2132 & 2176 & 12826 \\
\hline 35 & Drättinge & $2088+$ & $2085+$ & $12735+$ \\
\hline 36 & Hägerstad & $2062+51$ & $2059+51$ & 12760 \\
\hline 37 & Vigerstad & 2071 & 2068 & 12718 \\
\hline 38 & Räfstad & 2047 & 2044 & 12694 \\
\hline 39 & Ytterbo & $2015+$ & $2013+$ & 12663 \\
\hline 40 & Skedevi & 2019 & 2016 & 12666 \\
\hline 41 & Äfsinge & $1976+11+$ & $1976+11+$ & $12637+$ \\
\hline $42 b$ & Rimforsa & $1964+25+$ & $1964+25+$ & $12639+$ \\
\hline $43 a$ & Eknäs 2 & $1939+$ & $1939+$ & $12589+$ \\
\hline 45 & Vårdsnäs & 1873 & 1873 & 12523 \\
\hline 46 & Skaggebo & $1851+$ & $1851+$ & $12501+$ \\
\hline 47 & Bjärka-Säby & 1845 & 1845 & 12495 \\
\hline
\end{tabular}


Table 3. AMS ${ }^{14} \mathrm{C}$ dates from the glacial varves and their estimated calendar-year age BP. The calendar-year ages assigned to group A were obtained by synchronizing the records with the data set from Lake Gosciaz (Goslar et al. 1995. 1999), while the calendar-year ages in group B were obtained by calibrating the radiocarbon ages according to Stuiver \& Reimer (1993). $L=$ leaves, $L f=$ leaf fragment, $F=$ flower, $\mathrm{S}=$ seeds, UP $=$ unidentified plant remains, ${ }^{*}=$ plant remains possibly reworked, \# = uncertain age caused by fungi (see Wohlfarth $e t$ al. 1995). ${ }^{5}=$ The two ${ }^{14} \mathrm{C}$ ages from Toregöl were obtained on the same sample, therefore the weighted mean of the two dates was used for calibration. Samples marked with ${ }^{*}$ and \# are not included in Fig. 5a and 5c.

\begin{tabular}{|c|c|c|c|c|c|}
\hline Lab. No. & Locality & $\begin{array}{l}\text { Local } \\
\text { varve years }\end{array}$ & $\begin{array}{l}\text { Macrofossiis } \\
\text { submitted for AMS measurement }\end{array}$ & $\begin{array}{l}\text { AMS }{ }^{14} \mathrm{C} \text { date } \\
\text { yr BP }\end{array}$ & $\begin{array}{l}\text { Estimated } \\
\text { cal yr BP }\end{array}$ \\
\hline \multicolumn{6}{|l|}{ A. } \\
\hline Ua-4496 & Glottern & $1856 \pm 50$ & Salix/Betula (Lf) & $10585 \pm 465$ & 12506 \\
\hline Ua-10180 & Glottern & $1872 \pm 66$ & $\begin{array}{l}\text { Empetrum (L), Salix indet (Lf), Salix/Betula } \\
\text { (Lf), Dryas oct. (L), Arenaria (S), insects }\end{array}$ & $11550 \pm 300^{*}$ & 12522 \\
\hline Ua-10187 & Gummetorpasjön & $1938 \pm 4$ & Dryas oct. (L), Salix/Betula (Lf) & $10420 \pm 220$ & 12588 \\
\hline $\mathrm{Ua}-2544$ & Hargsjön & $1938 \pm 2$ & Dryas oct. (Lf, stem), Leguminosa (S) & $11405 \pm 145^{*}$ & 12588 \\
\hline Ua-10186 & Gummetorpasjön & $1968 \pm 25$ & Dryas oct. (L), Salix/Betula (Lf) & $11040 \pm 110$ & 12618 \\
\hline $\mathrm{Ua}-4359$ & Hargsjön & $1973 \pm 31$ & Dryas oct. (L), Salix polaris (L) & $10610 \pm 110$ & 12623 \\
\hline $\mathrm{Ua}-11527$ & Hargsjön & $1990 \pm 24$ & Salix indet. (Lf) & $10384 \pm 130 \#$ & 12640 \\
\hline $\mathrm{Ua}-4493$ & Adlerskogssjön & $2003 \pm 59$ & Salix polaris (L), Dryas oct. (L, F) & $\begin{array}{l}10830 \pm 165 \\
11230 \pm 100\end{array}$ & $\begin{array}{l}12650 \\
12659\end{array}$ \\
\hline Ua-10185 & Gummetorpasjön & $2009 \pm 16$ & $\begin{array}{l}\text { Salix reticulata (L), Salix polaris (L), } \\
\text { Salix indet. (Lf), Ericacea (L), Dryas oct. (L) }\end{array}$ & & \\
\hline Ua-2753 & Hargsjön & $2010 \pm 45$ & Betula/Salix (Lf), UP & $10480 \pm 150$ & 12660 \\
\hline Ua-10184 & Gummetorpasjön & $2044 \pm 16$ & Salix/Betula (Lf), Dryas oct. (L) & $10970 \pm 90$ & 12694 \\
\hline Ua-4358 & Hargsjön & $2055 \pm 50$ & Salix polaris $(\mathrm{L})$ & $10980 \pm 100$ & 12705 \\
\hline Ua-10183 & Gummetorpasjön & $2090 \pm 18$ & Dryas oct. (L), Betula/Salix (Lf) & $11030 \pm 120$ & 12740 \\
\hline Ua-11518 & Tynn & $2125 \pm 35$ & Salix/Betula (Lf), Dryas oct. (Lf, F) & $10511 \pm 130 \#$ & 12775 \\
\hline Ua-3131 & Tynn & $2125 \pm 35$ & Salix indet. (Lf), Dryas oct. (L, F), insects, UP & $10890 \pm 120$ & 12775 \\
\hline Ua-10182 & Gummetorpasjön & $2138 \pm 30$ & Ericacea (L, F), Salix/Betula (Lf), Dryas oct. (L) & $11470 \pm 130$ & 12788 \\
\hline Ua-11234 & Nedre Emmaren & $2146 \pm 23$ & $\begin{array}{l}\text { Salix indet. (Lf), Dryas oct. (L, S), Arenaria (L), } \\
\text { Salix polaris (L) }\end{array}$ & $10885 \pm 250$ & 12796 \\
\hline Ua-10181 & Gummetorpasjön & $2199 \pm 32$ & Saxifraga (F), Salix indet. (Lf), Silene (L) & $11450 \pm 240$ & 12849 \\
\hline Ua- 11233 & Nedre Emmaren & $2221 \pm 52$ & $\begin{array}{l}\text { Salix indet. (Lf), Salix polaris (L), Dryas oct. } \\
(\mathrm{L}, \mathrm{F}), \text { Betula nana }(\mathrm{L})\end{array}$ & $10745 \pm 240$ & 12871 \\
\hline \multicolumn{6}{|c|}{ 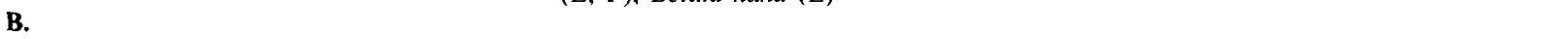 } \\
\hline Ua-4635 & Lillsjön & ? & Salix polaris (L), Salix/Betula (L), Dryas oct. (L) & $11895 \pm 860^{*}$ & \\
\hline $\mathrm{Ua}-4634$ & Lillsjön & ? & Salix polaris (L), Armeria, Dryas oct. (L) & $12320 \pm 470^{*}$ & \\
\hline $\mathrm{Ua}-4945$ & Lillsjön & ? & Salix/Betula (Lf) & $11530 \pm 130$ & $13480 \pm 130$ \\
\hline $\mathrm{Ua}-2750$ & Toregöl & ? & Dryas oct. (Lf), Betula/Salix (Lf), UP & $11520 \pm 225^{\mathrm{s}}$ & $13680 \pm 180$ \\
\hline Ua-2752 & Toregöl & $?$ & Dryas oct. (Lf), Betula/Salix (Lf), UP & $11820 \pm 150^{\mathrm{S}}$ & $13680 \pm 180$ \\
\hline
\end{tabular}

ated areas, which led to their isolation from the Baltic Ice Lake. Stratigraphically, these isolations are characterized by a cessation of varved-clay deposition, which was replaced by homogeneous clays and organic lacustrine deposits in most of the investigated sites.

\section{Field and laboratory methods}

We cored peat bogs and lakes (from ice in winter or close to the shore in summer), with a $1-\mathrm{m}$ long, modified and strengthened Russian corer with diameters of 10 and $7.5 \mathrm{~cm}$. At each site we obtained up to 10 parallel cores for each metre of varved clay and cored with an overlap of $50 \mathrm{~cm}$ in order to obtain sufficient organic material for dating. The cores were wrapped in plastic film and placed in half-PVC tubes for transport. In some cases, the same site was re-cored several times (Table 1 ).

In the laboratory, the cores were stored in a cold room $\left(+4^{\circ} \mathrm{C}\right)$ prior to analysis. Before the varve measurements were made, the core surface was cleaned and the overlapping cores were visually correlated to each other. A paper strip was then attached to the core surface and the thickness of each summer and winter layer was marked. The individual varve thickness obtained in this way was then measured and stored in data files. Based on the measured varve thickness, hand-drawn and computer-drawn diagrams were established. Correlations between the individual diagrams in the new chronology and to Kristiansson's varve diagrams were first made visually and then verified by cross-correlation analysis following the method developed by Holmquist \& Wohlfarth (1998).

Subsamples comprised $c$. $10-100$ varve-year segments and were sieved through a $0.5-\mathrm{mm}$ mesh. Dispersion of the clay particles was facilitated by storing the samples overnight in distilled water, to which a few drops of $5 \% \mathrm{Na}_{4} \mathrm{P}_{2} \mathrm{O}_{7}$ were added. Visible macrofossils were picked out during sieving, identified and submitted for AMS ${ }^{14} \mathrm{C}$ measurements (Wohlfarth et al. 1995). Only clearly determinable terrestrial macrofossils, such as leaves, seeds or flowers of typical Late Weichselian plants (Liedberg-Jönsson 1988) were then selected under the binocular for dating. 
To estimate variations in the amount of mineral grains, additional subsamples from Gummetorpasjön 2 and Glottern were sieved and grains $>0.5 \mathrm{~mm}$ were counted. The subsamples covered between 8 and 77 varve years. The amount of mineral components is expressed as grains $/ \mathrm{mm}^{2} /$ year.

\section{Results}

\section{The new varve chronology}

As shown in Figs. 1B and 2, the new varve diagrams were established close to sites that were previously investigated by Kristiansson. However, owing to the uncertain varve-diagram correlations in Kristiansson's chronology (Holmquist \& Wohlfarth 1998), it was not possible simply to add the new diagrams to the existing chronology. Instead, we firstly built up a chronology based on the new varve diagrams, which we correlated to each other from north to south. In this way it was possible to create a continuous chronology between the sites Limmern (Fig. 3C) and Tynn-Tyllinge (Fig. 3A), which comprises 658 varve years. The visual correlation between these diagrams, which is supported by statisti$\mathrm{cal}$ analyses, was facilitated by the alternation of thicker and thinner varves, distinct colour changes and especially thick clayey winter layers. In order to avoid the use of new local varve years, we adopted Kristiansson's time scale by linking the characteristic thick clayey varves in the site Glottern 2 to Kristiansson's sites 41 Äfsinge and 42b Rimforsa (local varve years 1938 1941) (Fig. 3C). The good correlation between site 41 and $42 \mathrm{~b}$ had previously been indicated by cross-correlation analysis (Holmquist \& Wohlfarth 1998). In a second step, we matched Kristiansson's diagrams (14, $16-18,20-33,35-47)$ to this chronology. This correlation implied a slight revision of their published varve ages (Table 2) and allowed extension of the chronology by 114 years (Fig. 3A).

No statistically valid correlations could be found between the new diagrams (Svartgöl, Svarteln, St. Älviken, Nässjön, Lillsjön, Horsebergasjön and Toregöl) situated further to the south (Fig. 1, Table 1). This is due to the strongly varying varve-thickness pattern and/or to the fairly large distance between single diagrams. Whereas the Svartgöl and Lillsjön sites exhibit fairly thick varves, Svarteln, St. Älviken and Nässjön are characterized by mainly thin varves. Toregöl and Horsebergasjön are situated close to each other and both sequences show a distinct change in varve thickness, but their correlation is statistically insignificant. The cross-correlation analysis performed earlier between Kristiansson's diagrams (sites 1-13 in Figs. 1 and 2) showed no statistically valid correlation (Holmquist \& Wohlfarth 1998), which makes it impossible to use these sites for an extension of the chronol-

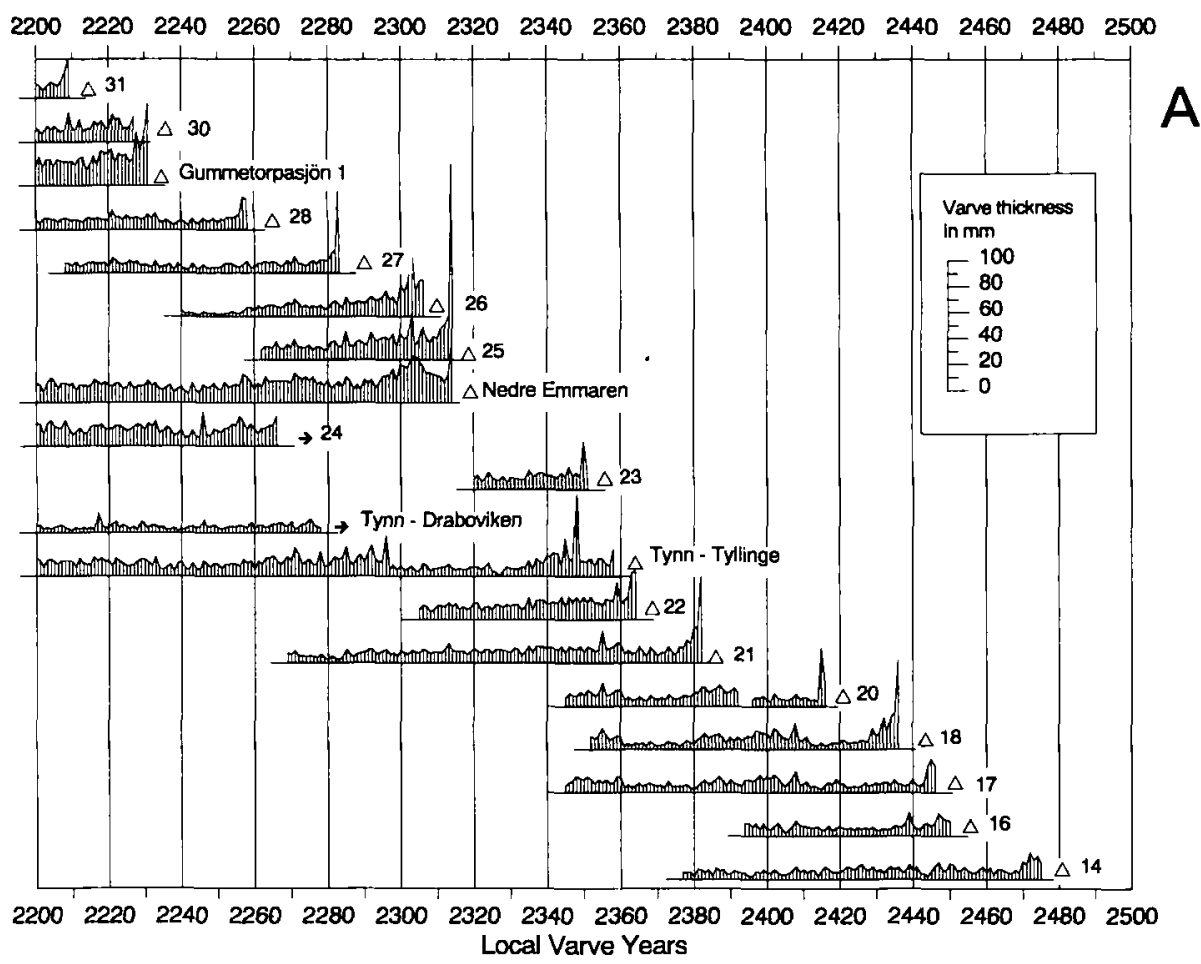

Fig. 3. $\square A-C$. Correlations between the varve diagrams from localities listed in Tables 1 and 2. Open triangles indicate that the bottom varves have been reached and arrows show that more varves may be present in the basal part of the sequences. See Figs. 1 and 2 for the location of the sites. 


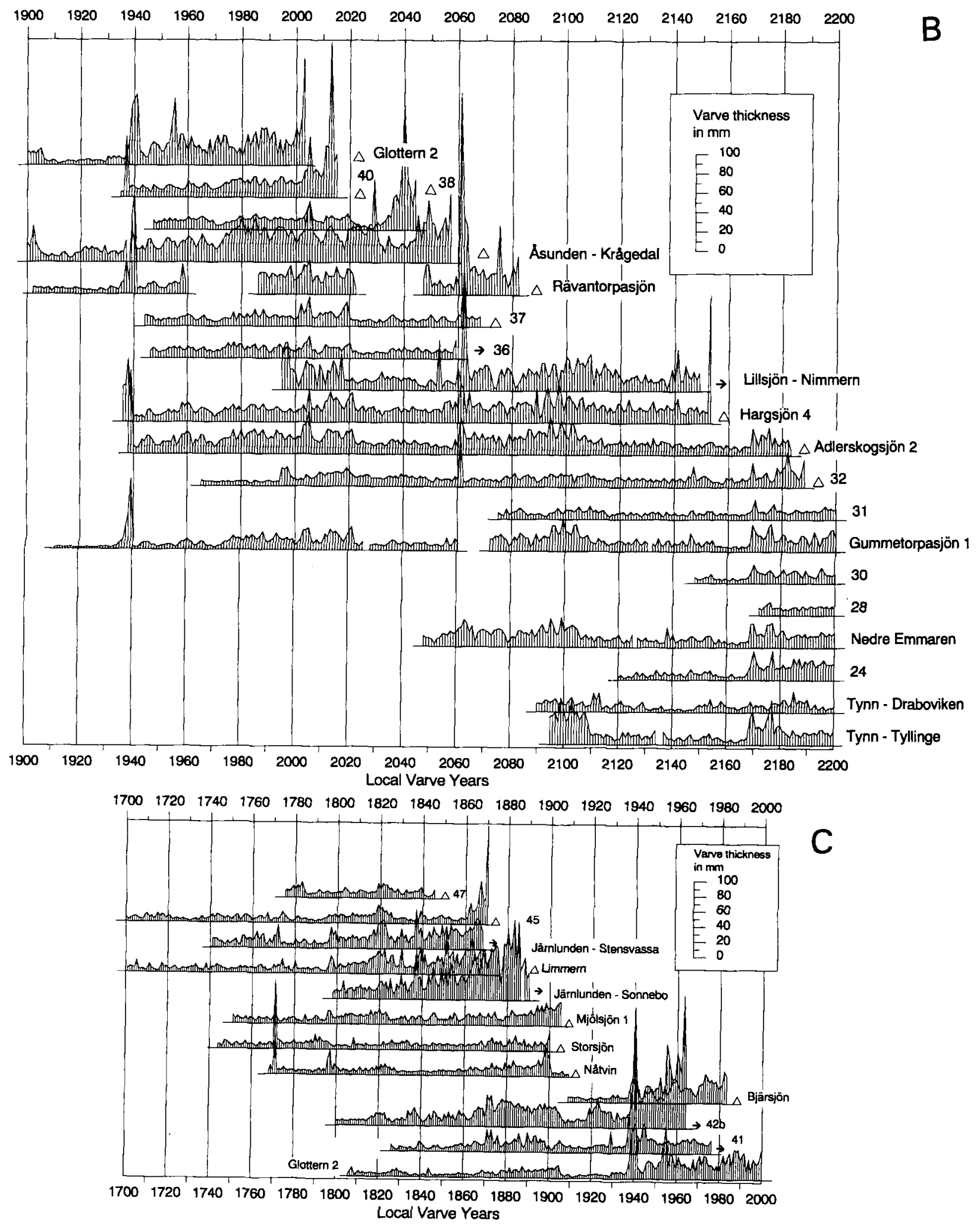

Fig. 3. Continued 
ogy. The diagrams, which were established by Kristiansson on localities further to the east (sites 77-91 in Fig. 1) are neither significantly correlated at the published match (Holmquist \& Wohlfarth 1998), nor could they be correlated to the new chronology.

\section{Lithology of the varved clays}

The southernmost sites Toregöl and Horsebergasjön (Figs. 1 and 2) are both characterized by a distinct change in varve thickness, from thin $(<5 \mathrm{~mm})$ to thicker varves $(>10 \mathrm{~mm})$. Although this change in varve thickness seems to be characteristic for the area, a varve-to-varve correlation to sites $1,2 \& 3$ is not possible. The sequence from Lillsjön, on the other hand, displays mainly fairly thick varves $(>10 \mathrm{~cm})$ varves, which must have occurred in connection with the deposition of these thick varves. Starting with the year 2060, the varves become generally thinner again, with summer layers $(2-6 \mathrm{~mm})$ being dark brown and winter layers $(5-10 \mathrm{~mm})$ reddish brown, but after a period of c. 40 years varve thickness increases again. In Rävantorpasjön, two periods with disturbed and folded varves fall within this time frame (Fig. 3B). Mineral debris $(>0.5 \mathrm{~mm})$ decreases to 0 grains $/ \mathrm{mm}^{2}$ ) year between the local varve years $2130-2010$, but increases again to $0.2-0.8$ grains $/ \mathrm{mm}^{2} /$ year between 2010 and 1950 (Fig. 4). The varve years $1942-1937$ are similar to the years 2064-2061 and are characterized by exceptionally thick winter (up to $70 \mathrm{~mm}$ ) and thin summer layers ( $<5 \mathrm{~mm}$ ) (Fig. 3C). However, a change in colour occurred as early as around the years 19461942. The summer layers are generally brown and, in some cases sandy, while the winter layers have a distinct blue-beige colour. Erosional features, such as 'missing' varves were observed in Åsunden-Krågedal. Coincident with the occurrence of these thick varves, mineral debris increases drastically (from 0.2 to 6.7 grains $/ \mathrm{mm}^{2} /$ year) (Fig. 4). During a short period of $c$. 30 years (varve years 1936-1906), colour and varve thickness change again and the grey-brown summer and brown winter varves are fairly thin, and total varve thickness rarely attains $10 \mathrm{~mm}$. Although some varve sequences show a varying varve thickness pattern also between the years 1905/1900 and 1701 (Fig. 3C), these features are less characteristic. Generally, thicker varves occur between the years 1900 and 1860,1825 and 1796, 1773 and 1701 and thinner varves between the years 1860 and 1825 and 1796 and 1773. A change in colour could, however, only be observed in Mjölsjön and Limmern at the local varve year 1796. In these two sequences, the varves between $c .1825$ and 1796 show light-brown to greyish summer and reddish-brown winter layers, which grade into light-greyish brown summer and grey-brown winter layers between 1796 and 1773. A gradual increase in mineral debris from 1.3 to 2.7 grains $/ \mathrm{mm}^{2} /$ year can be observed between the years 1940 and 1810 (Fig. 4). A thick winter layer in the varve year 1771 is only present in the sequences from Nåtvin and Storsjön (Fig. 3C).

\section{Macrofossil content of the samples and $A M S{ }^{14} \mathrm{C}$ measurements}

Out of the 25 investigated sites only 9 sites contained terrestrial plant remains (Toregöl, Lillsjön, Svartgöl, Tynn, Nedre Emmaren, Gummetorpasjön, Adlerskogssjön, Glottern and Mjölsjön). Sites where varved clays were deposited in fairly deep water, e.g. to the north and east of the archipelago landscape, were completely devoid of plant remains. However, sufficient amounts of terrestrial macrofossils for radiocarbon measurements could be found in a few sites close to the highest shoreline, and these were re-cored several times (Tables 1 and 3).

The plant macrofossils selected for radiocarbon measurements included mainly leaves and leaf fragments of Dryas octopetala, Betula nana and Salix polaris, but also leaves of Armeria, Silene, Salix reticulata and Ericaceae (Table 3). Owing to fragmentation it was sometimes difficult to identify the Salix species or to distinguish between Salix and Betula. In a few cases fragments of flower stems could be identified to Salix, Saxifraga and/or Dryas octopetala. Seeds and fruits of Dryas octopetala, Arenaria, Leguminosa and Ericaceae were very rare. Unidentified leaves of terrestrial macrofossils and insects were added to two of the samples in order to increase the sample weight (Table 3).

With the exception of the samples from the Toregöl and Lillsjön sites, which are situated south of the continuous chronology, local varve years could be assigned to each sample (Table 3 ). The range of the dates is fairly homogeneous, when compared to their

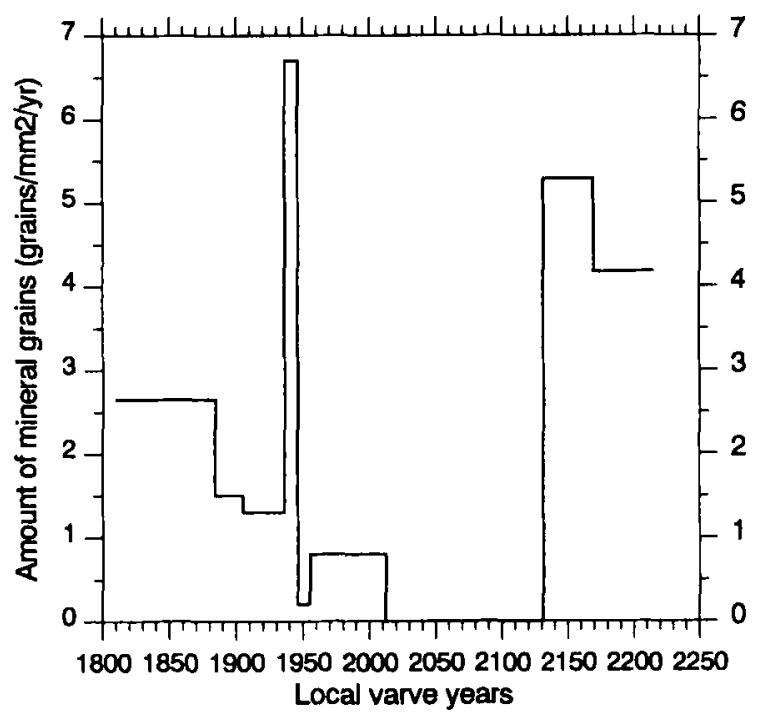

Fig. 4. The amount of mineral debris (grains $/ \mathrm{mm}^{2} / \mathrm{yr}$ ) in samples from Gummetorpasjön and Glottern plotted against local varve years. 

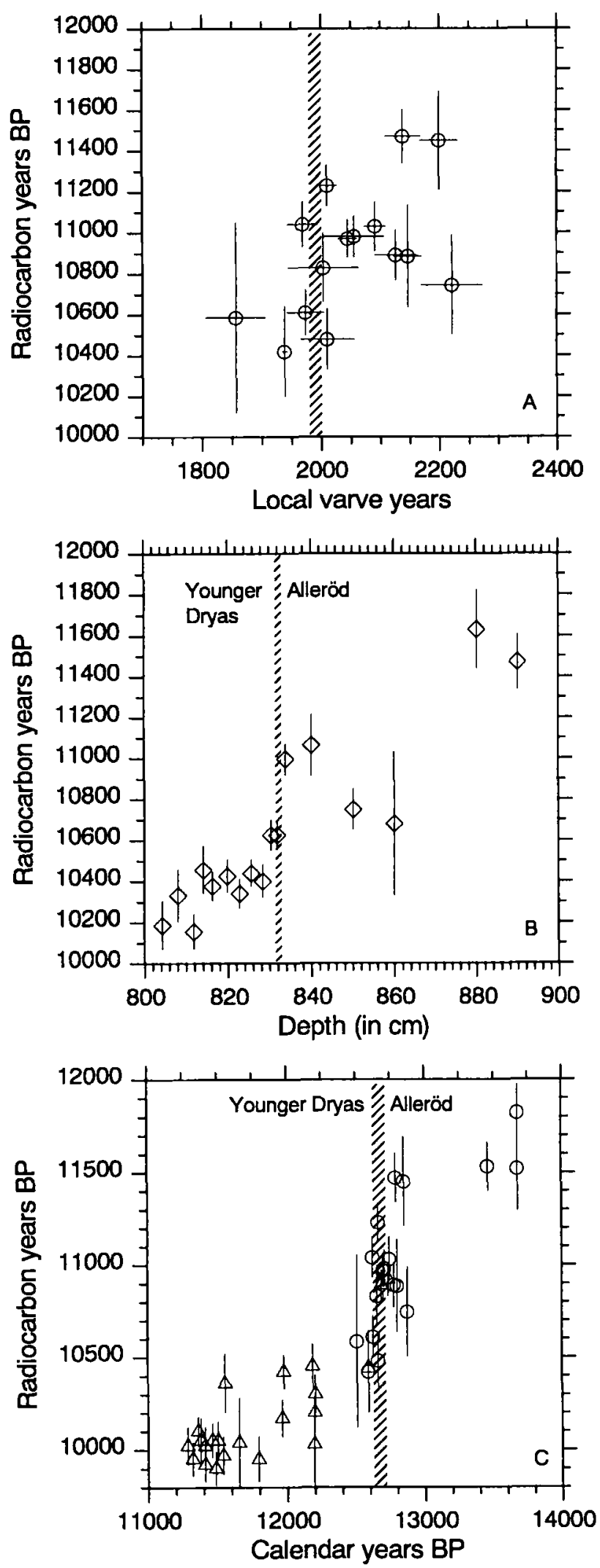

Fig. 5. local varve years, although some samples are clearly older or younger than duplicate samples from corresponding varve years. Samples with distinctly older ages (Ua-2544, Ua-10180, Ua-4635, Ua-4634) are, therefore, interpreted as having been composed of reworked plant material, while those with too young ages (Ua-11527, Ua-11518) had been affected by fungi (Wohlfarth $e$ t al. 1998).

Tentative calendar-year age assignment of the floating varve chronology

The AMS ${ }^{14} \mathrm{C}$ dates plotted in Fig. 5a show a distinct drop in ages from $c .11000{ }^{14} \mathrm{C} \mathrm{BP}$ to $c .10600-10800$ ${ }^{14} \mathrm{C}$ BP between the local varve years 1950 and 2000 . This drastic change in radiocarbon ages can also clearly be seen in the sediment records from Lake Madtjärn (Björck et al. 1996) and Lake Gosciaz (Goslar et al. 1995). In both sites it coincides with the pollenstratigraphic boundary between the Allerød and Younger Dryas biozone (Figs. 5B, C). However, only Lake Gosciaz consists of annually laminated sediments and has, through 'wiggle-matching' been linked to the dendro-calibration curve (Goslar et al. 1995; Goslar \& Madry 1998). This link gave a best estimate of $11511 \pm$ 36 calendar years BP for the Younger Dryas-Preboreal boundary and of $12650 \pm 60$ calendar years BP for the Allerød-Younger Dryas boundary (Goslar \& Madry 1998).

A best fit between the data set from Gosciaz and the Swedish varves may be obtained, when the two records are synchronized through the rapid drop of radiocarbon ages over the Allerød-Younger Dryas boundary (Goslar et al. 1999). This means, setting the local varve year 2000 equal with a calendar-year age of $c .12650 \pm$ 60 BP (Fig. 5C). Such a correlation is broadly in agreement with pollenstratigraphic investigations, which have been performed on varved clays from Gummetorpasjön, Glottern and Mjölsjön (J. Björck personal communication 1998). They showed that the pollen-stratigraphic transition might have occurred at around the local varve year 1900 , but they indicate also that the transition could be placed anywhere between the local varve years 1840 and 2000 (J. Björck pers. comm. 1998). The difference between the pollen-stratigraphic defined Allerød-Younger Dryas boundary in

Fig. 5. $\square$ A. AMS ${ }^{14} \mathrm{C}$ dates on terrestrial plant macrofossils from the varved clays (open circles) plotted against local varve years. The AMS ${ }^{14} \mathrm{C}$ dates which are uncertain (see Table 3 ) are not included in the figure. The shaded area indicates the drop in radiocarbon ages around the local varve year 2000. $\square$ B. The radiocarbon ages from Lake Madtjärn (open diamonds), plotted against depth and in relation to the pollen stratigraphic position of the Allerød-Younger Dryas boundary (Björck et al. 1996). $\square$ C. Comparison of the synchronized radiocarbon dates from the varved clays (open circles) against to the AMS ${ }^{14} \mathrm{C} / \mathrm{varve}$ record from Lake Gosciaz (open triangles) (Goslar et al. 1995; Goslar et al. 1999). All error bars represent a one standard deviation. 


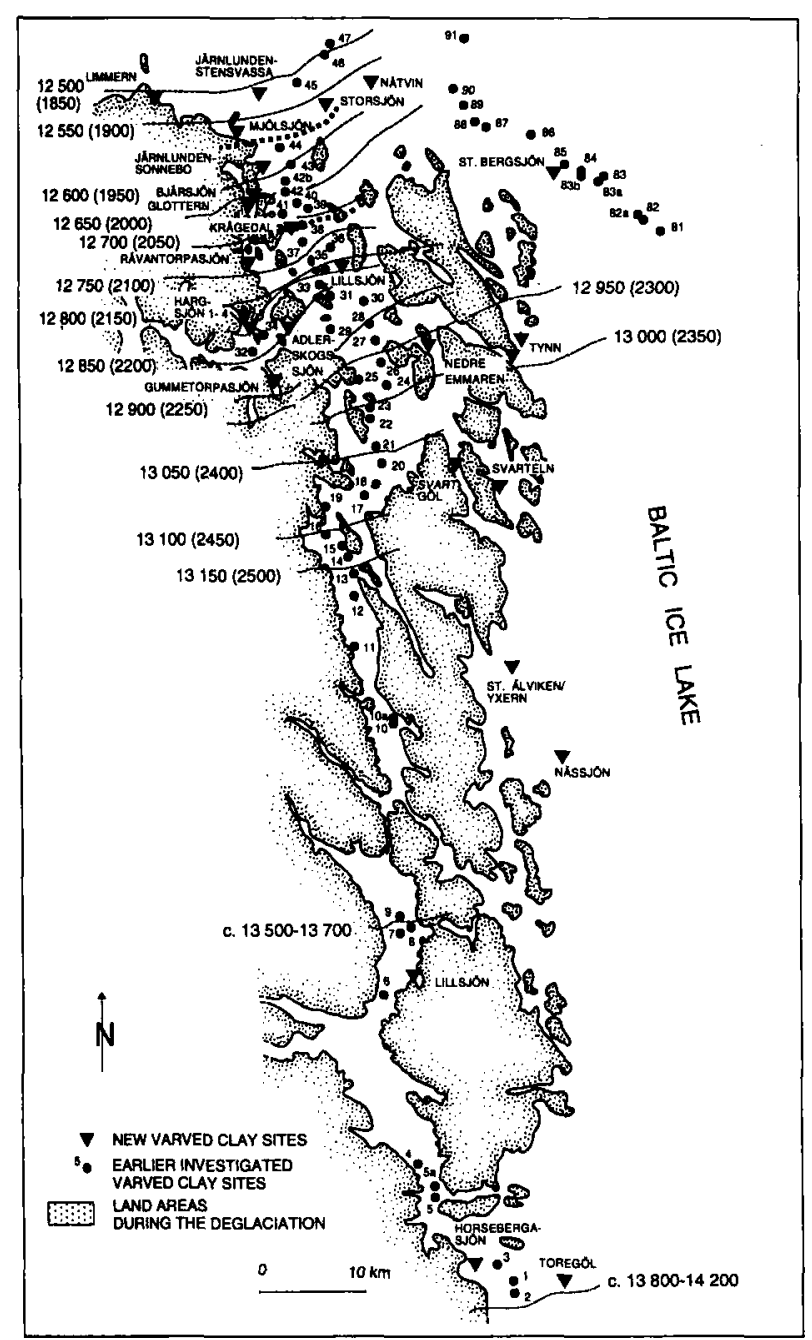

Fig. 6. Ice recession lines for the northern part of the investigated area based on the varve-diagram correlations presented in Fig. 3. The calendar-year age assignment is tentative (see text). The position of the ice margin during the deposition of the thick varves at the loca varve year $2169 / 2168,2061 / 2060$ and $1946-1942$ is indicated by dotted lines. See Fig. 1B for the geographical position of this map.

the varved clays and that obtained through the synchronization may be artificial. The error margins of the few radiocarbon dates, which point to a Younger Dryas age, are fairly large (Fig. 5A) and a shift by, for example, 100 varve years could be possible. On the other hand, a distinct Younger Dryas pollen signal may be smoothed out in the varved clays, because of the amount of redeposited pollen grains in the pollen spectra (J. Björck pers. comm. 1998).

The correlation between the new varve chronology, Lake Gosciaz and Lake Madtjärn makes it possible to assign tentative calendar-year ages to the radiocarbon samples (Table 3). By setting the local varve year 2000 equal with the Allerød-Younger Dryas transition, or a calendar-year age of $12650 \pm 60 \mathrm{BP}$, the calendaryear ages of the bottom varves in each diagram can be estimated (Tables 1 and 2). They show that the varve chronology ranges between c. 13125 and c. 12350 calendar years BP and covers the youngest part of the Allerød and the oldest part of the Younger Dryas. Since it was not possible to establish a continuous varve chronology further south of site no. 14 (Fig. 2), the radiocarbon dates from the two 'floating chronologies' Lillsjön and Toregöl were calibrated to calendar years using the calibration programme of Stuiver \& Reimer (1993) (Table 3).

\section{Deglaciation chronology: varve, radiocarbon and calendar years}

The varve chronology established between sites 14 and 47 (Fig. 3) shows that the northern part of the inner archipelago became ice free between the local varve years 2500 and 1850 or, between $c .13150$ and $c .12500$ calendar years BP (Fig. 6). Corresponding radiocarbon ages (for the local varve years 2270-1800) range between $c .11500-10500{ }^{14} \mathrm{C}$ BP. These ages, together with pollen-stratigraphic investigations and the synchronization outlined above, indicate that the area between Glottern and Limmern became deglaciated during the earliest part of Younger Dryas, i.e. between the local varve years $2000-1850$ or c. $12650-12500$ calendar years BP (Fig. 6). This is in contrast to Kristiansson (1986), who placed the beginning of the Younger Dryas at the local varve year 1760 , which is c. 100-250 years later than our estimate. However, his conclusion was based on a slow-down of the ice recession rate and a stagnation of the ice margin. It may be possible that the inland ice reacted with a certain delay to the cooling, but it may also be possible that a revision of Kristiansson's varve-diagram correlations may lead to a different picture regarding the ice recession lines.

The continuous chronology extends only as far south as site 14, or back to $c .13150$ calendar years BP (Fig. 6). Further south, the deglaciation may be estimated based on a calibration of the radiocarbon dates from Lillsjön and Toregöl and a correlation of these two varve diagrams to nearby sites. The dates from both Lillsjön and Toregöl give a minimum age of $c .11500-$ $11800{ }^{14} \mathrm{C}$ BP for the deglaciation of the southern part of the archipelago (Table 3). The varve diagram from Lillsjön correlates well to the varve diagrams from sites $6-9$. This correlation indicates that the bottom varves were not recovered from Lillsjön and that sites 8 and 9 had become ice free $c .130$ years before the deposition of the lowermost varves in Lillsjön. If we assume a calibrated age of $c .13350-13610 \mathrm{BP}$ for the varves in Lillsjön (Table 3), the deglaciation of sites 8 and 9 may thus have occurred sometime between $c$. 13 460-13740 calendar years BP (Fig. 6). A direct correlation between the varve diagram from Toregöl and those from sites 1-3 was not possible. However, the distinct change in 

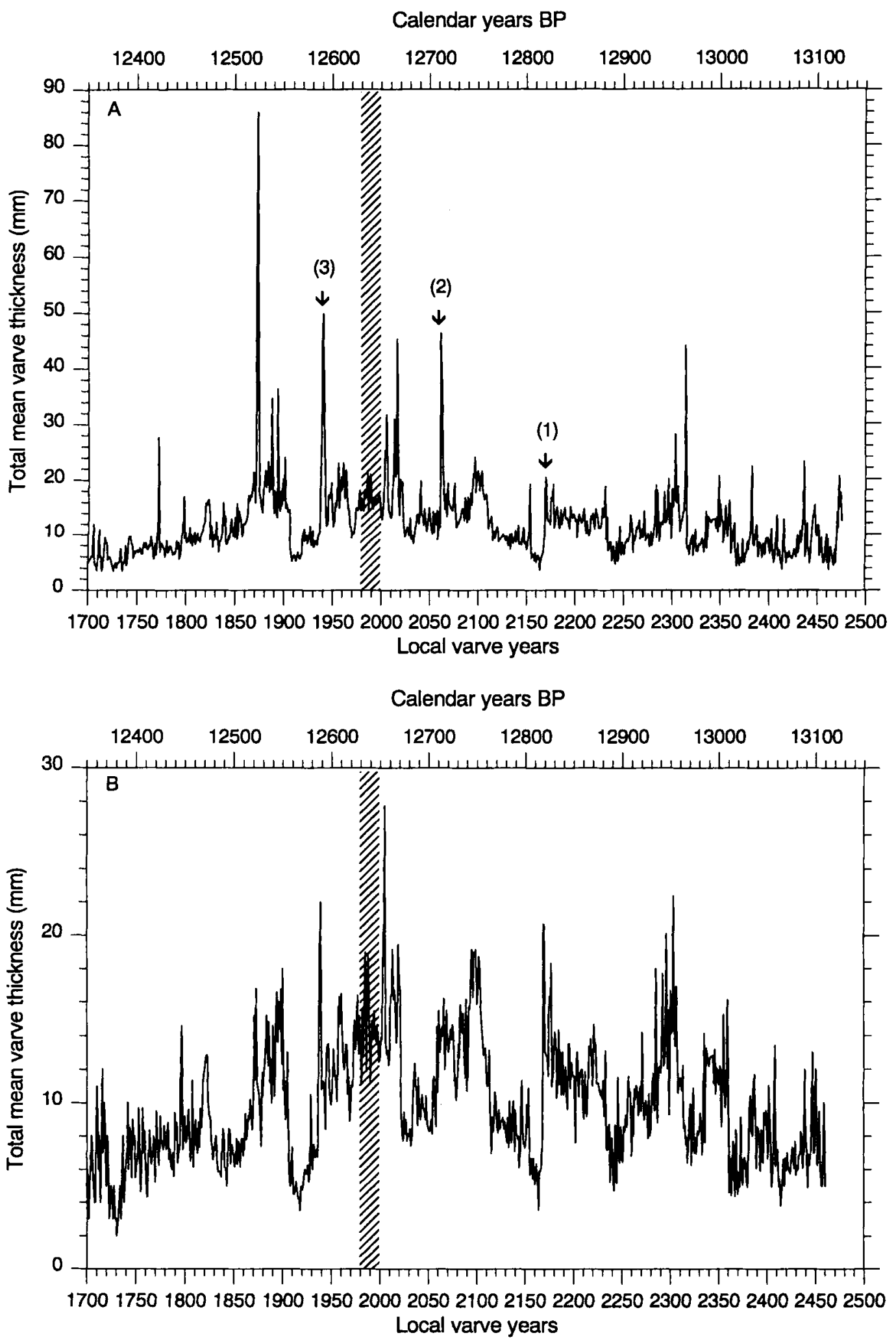

Fig. 7. $\square$ A. Total mean varve thickness curve based on all varve diagrams listed in Tables 1 and 2 . The position of the exceptionally thick varves and the colour changes around the varve years 2169/2168,2061/2060 and 1946-1942 is indicated with an arrow. $\square$ B. Filtered total mean varve-thickness curve based on the varve diagrams shown in Fig. 5a-C (see text for details). Bottom varves, exceptionally thick varves and the diagrams from Järnlunden-Stensvassa, Järnlunden-Sonnebo, Rimforsa and Limmern are excluded. The shaded area indicates the Allerød-Younger Dryas transition. 
varve thickness from thin and compact to thicker varves is also visible in the diagrams from sites $1-3$ and may be used as a tentative match. In these latter diagrams, up to $c .350$ varves were measured below the transition. Based on the assumption that the transition from thin to thick varves occurred at the same time in Toregöl and in sites $1-3$, we may conclude that the area around Toregöl became ice free $c .350$ years before the deposition of these thicker varves. The radiocarbon dates from Toregöl (11520 225 and $11820 \pm 150^{14} \mathrm{C}$ $\mathrm{BP}$ ), which were obtained on the first 29 thick varves gave a weighted mean age of $11728 \pm 125{ }^{14} \mathrm{C}$ BP (Table 3 ). The calibrated date of the weighted mean age is $c .13680 \pm 180$ calendar years BP. An addition of $c$. 350 years would lead to an age of between $c .13800$ and 14200 calendar years BP for the deglaciation of the area around Toregöl (Fig. 6). These ages correspond approximately to the calendar-year ages between late Bølling to early Allerød in the GRIP ice core (Johnsen et al. 1992). Compared to radiocarbon-dated pollen stratigraphies from southern Sweden (Björck \& Möller 1987), our radiocarbon dates show that the deposition of the thick varves in Toregöl occurred during the earlier part of Allerød. Taken together, we can conclude that the area around Toregöl became ice free somewhere between late Bølling/Older Dryas/early Allerød.

\section{Varve-thickness variations}

Recurrent features in the varved clays are the three distinct colour and thickness changes (from thick to thin varves) which can be observed at around the local varve years 2169/2168, 2061/2060 and 1946-1942 (Figs. 3A-C, 7A). Events 1 and 2 occurred during the later part of the Allerød at c. $12819 / 12818$ and $c$. $12711 / 12710$ calendar years BP and event 3 is visible shortly after the transition into the Younger Dryas at between c. 12596 and 12592 calendar years BP.

The synchronous change in colour and varve thickness at event 1 is followed by an increase in mineral debris. The event can be traced from Gummetorpasjön to Tynn (Figs. 3B, 6). The marked colour change during event 2 was preceded by $2-4$ varves with exceptionally thick winter layers and this can be seen in the diagrams from Nedre Emmaren, Adlerskogsjön, Hargsjön, Lillsjön-Nimmern and Rävantorpasjön. No mineral debris $>0.5 \mathrm{~mm}$ was observed during event 2 . The third distinct change in colour, which is visible as far to the south-east as Nedre Emmaren, was followed by varves with several thick winter layers between the years 1942 and 1937 (Figs. 3B, 3C, 6). Coincident with the thick varves, the amount of mineral debris increases drastically and one radiocarbon date from Hargsjön, which covers the local varves 1936-1940, indicates reworked plant material (Table 3). Although all three events are characterized by colour and varve thickness changes, their development is slightly different. While varve thickness and colour change simultaneously during event 1 , a colour change precedes the few exceptionally thick clayey varves of events 2 and 3 , which are in turn followed by thin varves (Figs. $3 B$ and $C$ ).

During the deglaciation, several local ice lakes existed in areas above the highest coastline. The largest of these were the Sommen and Drögen ice lakes, which were situated to the west of the investigated area (Agrell 1976). Kristiansson (1986) related especially thick varves around the local varve years 2008 and 1940 to the drainage of the Drögen ice lake. Following Agrell, the Sommen ice lake had an outlet through the west-east oriented valley between Hargsjön and Gummetorpasjön (Fig. 6). This valley became ice free around event 1, when the ice margin was situated between site 32 and Hargsjön. Event 2 occurred when the ice margin was situated between site 37 and 38 and slightly north of Rävantorpasjön. It is not possible exactly to determine the position of the ice margin during event 3 , but it must have been situated slightly north of the recession line 1950 (Fig. 6). Such a position opened up the valley, where Bjärsjön and Glottern are situated and which has been regarded as a likely pathway for the drainage of the Drögen ice lake (Agrell 1976).

The sudden drainage of local ice dammed lakes must have released a considerable amount of sediment material into the Baltic Ice Lake. The occurrence of exceptionally thick clay layers compared to thin silt layers, erosion features in some sequences (events 2 and 3 ), the increase in mineral debris and the presence of reworked plant material (event 3) may indicate that events 2 and 3 reflect such a sudden drainage. However, event 1 , although followed by an increase in mineral debris, is not characterized by equally thick clay layers and does, therefore, not fit into the idea of a sudden and shortlived drainage event. Furthermore, it is difficult to explain why such drainage events are accompanied by a change in colour and why they are followed by a drastic reduction in varve thickness (Fig. 7A). The granite bedrock around Sommen and Drögen does not differ, with the exception of the occurrence of volcanic rocks, from that in the archipelago area, which means that a colour change could not have been caused by a difference in bedrock material. Deposition of thin varves generally occurs in deeper parts of the Baltic Ice Lake basin (e.g. Nässjön, St. Ålviken or St. Bergsjön), during periods of reduced melting or in areas distant to the active ice margin (Wohlfarth et al. 1994). However, the varves within the archipelago were deposited in fairly shallow water and close to the ice margin.

In order to obtain a varve-thickness diagram, which is not influenced by extremely thick varves, such as bottom varves or varves that were deposited during events $1-3$, we constructed a 'filtered' mean varvethickness diagram (Fig. 7B). In this diagram, we deleted the thick bottom and 'drainage' varves in all 
sequences and excluded diagrams with especially thick varves, such as Rimforsa, Järnlunden-Stensvassa, Järnlunden-Sonnebo and Limmern (see Fig. 5C). When these varves are removed, the thickness variation displays an almost cyclic pattern between thicker and thinner varves and a slight trend of increasing/decreasing varve thickness before and after the year 2000 . With the exception of the period between the years 2240 and 2100 , each cycle displays a saw-tooth shape and starts with thicker varves, which gradually become thinner until the thickness increases again abruptly. During the first c. 200 years, between 2460 and 2250, the time difference between the peaks in varve thickness seems to range around $40-60$ years. Between the years 2100 and 1720 , the cycles become longer and attain approximately $80-120$ years. A likely explanation for this cyclic behaviour may be alternating periods of increased and decreased melting of the decaying ice sheet, rather than water level changes in the Baltic Ice Lake or an oscillating ice margin.

Events 2 (varve year 2061/2060) and 3 (varve year 1942-1937) seem to be superimposed on the slopes of decreasing varve thickness. However, before and after event 1 , i.e. between the years 2250 and 2100 , the gradual decrease in varve thickness is reversed and, instead, a trend with gradually increasing varve thickness, which is followed by an abrupt decrease, can be observed (Fig. 7B). The absence of thick clay layers and the break in general varve thickness pattern before and after event 1 argue against a sudden drainage from local ice-dammed lakes. However, the rapid decrease in varve thickness at event 1 may be indicative of a hiatus caused by, for example, a drainage event or by a sudden lowering of the water level in the Baltic Ice Lake.

\section{Conclusions and implications}

A radiocarbon-dated floating 800-year long varve chronology has been established along the Swedish east coast. Through a synchronization of the radiocarbon dates with Lake Madtjärn (Björck et al. 1996) and the laminated sediment sequence from Lake Gosciaz (Goslar et al. 1995), the transition between Allerød and Younger Dryas could be set equal to the local varve year 2000 . The synchronization shows, that the northern part of the investigated area became ice free during the later part of the Allerød, and during the early Younger Dryas, i.e. between c. 13150 and 12500 calendar years BP. The beginning of the Younger Dryas (local varve year 2000), occurred in our chronology a few hundred years earlier than previously estimated by Kristiansson (1986).

Varve diagrams from the southern part of the investigated area could not be correlated to the 800-year long chronology. However, based on a combination of calibrated radiocarbon years and varve years, we assume that the southernmost part became ice free as early as during the later part of Bølling or at the Bølling/Older Dryas transition (c. 14 200-13 800 calendar years BP). If this assumption is correct, the deglaciation of the whole area (between sites 1 and 47) occurred during a time period of approximately $1700-$ 1300 years. This is considerably longer than the $900-$ 1000 years proposed by Kristiansson (1986). Our estimates are, however, in agreement with the findings that a considerable number of varve years are 'missing' in the older part of Kristiansson's chronology (Wohlfarth 1996). They are further in line with varve diagram correlations in southern Sweden, which show a rapid ice retreat along the southeasternmost part of the Swedish east coast (Fig. 1A) (Ringberg 1991; Brunnberg, pers. comm. 1998). Pollen-stratigraphic investigations and radiocarbon dates indicate that varves in southern Sweden were deposited between Bølling and Older Dryas (Björck \& Möller 1987; Wohlfarth et al. 1994, 1995; Ising in press). The pollen-stratigraphic transition between Bølling and Older Dryas in this local varve chronology, which was established by Ringberg (1991), was placed at around the local varve year +220 by Wohlfarth et al. (1994) and Ising (in press). This transition corresponds to approximately 14100 calendar years in the GRIP ice core (Johnsen et al. 1992). The south-east coast became, however, already ice free between the local varve years -100 to +20 in Ringberg's (1991) chronology, which would correspond to about 14 400-14300 calendar years BP. Although these calendar year ages are only rough estimates, they show in accordance with the radiocarbon dates and with Björck \& Möller (1987) that the active ice margin must have retreated from southernmost Sweden up to Högsby within a few hundred years only. Large areas above the highest coastline, which are today characterized by a hummocky moraine landscape, remained covered by stagnant ice (Björck \& Möller 1987) and continued to contribute sediment material to the Baltic Ice Lake.

Acknowledgements. - This study was financed by the Swedish Natural Science Research Council (NFR) and the Geological Survey of Sweden (SGU). We extend our thanks to the following colleagues for their help in the field and in the laboratory: Jessica Ademark, Lars Brunnberg, Jonas Björck, Felicia Dobos, Björn Gedda, Dan Hammarlund, Björn Holmquist, Julia Meyer, Tomas Nilsson, Markus Olsson, Siv Olsson, Per Sandgren, Timo Saarinen and Peter Svensson. Geoffrey Lemdahl and Gina Hannon helped to identify the macrofossils. We are grateful to Tomasz Goslar for a careful review of the manuscript and to Ian Snowball for correcting the language.

\section{References}

Agrell, H. 1976: The highest coastline in south-eastern Sweden. Boreas 5, 143-154.

Agrell, H., Friberg, N. \& Oppgården, R. 1976: The Vimmerby line - an ice-margin zone in north-eastern Småland. Svensk Geografisk Årsbok 52, 71-91. 
Berglund, B. E. 1979: The deglaciation of southern Sweden, 13,500-10,000 BP. Boreas 8, 89-118.

Björck, S. 1995: A review of the history of the Baltic Sea, 13.0-8.9 ka BP. Quaternary International 27, 19-40.

Björck, S., Cato, I., Brunnberg, L. \& Strömberg, B. 1992: The clay-varve based Swedish Time Scale and its relation to the Late Weichselian radiocarbon chronology. In Bard, E. \& Broecker, W S. (eds.): The Last Deglaciation: Absolute and Radiocarbon Chronologies, 25-44. Springer, Berlin.

Björck, S., Kromer, B., Johnsen, S., Bennike, O., Hammarlund, D. Lemdahl, G.. Possnert, G., Rasmussen, T. L., Wohlfarth. B., Hammer, C. U. \& Spurk, M. 1996: Synchronised terrestrial-atmospheric deglacial records around the North Atlantic. Science $274,1155-1160$.

Björck, S. \& Möller, P. 1987: Late Weichselian environmental history in southeastern Sweden during the deglaciation of the Scandinavian ice sheet. Quaternary Research 28, 1-37.

Brunnberg, L. 1995: Clay-varve chronology and deglaciation during the Younger Dryas and Preboreal in the easternmost part of the Middle Swedish Ice Marginal Zone. Quaternaria, Ser. A, No. 2. 3-94.

Cato, I. 1987: On the definitive connection of the Swedish Time Scale with the present. Sueriges Geologiska Undersökning, $\mathrm{Ca} 68$, $1-55$

De Geer, G. 1912: A geochronology of the last 12,000 years. Congrès de Geologie International, Comptes rendues, 241-253.

Goslar, T, Arnold, M., Bard, E., Kuc, T., Pazdur, M. F., RalskaJasiewiczowa. M., Rozanski, K., Tisnerat, N., Walanus, A. Wicik, B. \& Wieckowski, K. 1995: High concentration of atmospheric ${ }^{14} \mathrm{C}$ during the Younger Dryas cold episode. Nature 377, 414-417.

Goslar, T. \& Madry, W. 1998: Bayesian method to study the precision of dating by means of the 'wiggle matching' procedure. Radiocarbon 40 (in press).

Goslar, T., Wohlfarth, B., Björck, S., Possnert, G. \& Björck, J. (1999): Variations of atmospheric ${ }^{14} \mathrm{C}$ concentrations over the Allerød-Younger Dryas transition. Climate Dynamic's 15, 29-42.

Holmquist, B. \& Wohlfarth, B. 1998: An evaluation of the Late Weichselian Swedish varve chronology based on cross-correlation analysis. GFF 120/1, 35-46.

Ising, J. (in press): Late Weichselian pollen stratigraphy, clay-varve chronology, radiocarbon chronology and palaeomagnetic secular variations in Farslycke, central Blekinge, south Sweden. GFF (in press).

Johnsen, S. J., Clausen, H. B., Dansgaard, W., Fuhrer, K., Gundestrup, N., Hammer, C. U., Iversen, P., Jouzel, J., Stauffer, B. \& Steffensen, J. P. 1992: Irregular glacial interstadials recorded in a new Greenland ice core. Nature 359, 311-313.

Kristiansson, J. 1986: The ice recession in the south-eastern part of Sweden. University of Stockholm, Department of Quaternary Research, Report 7, 133 pp.

Liedberg-Jönsson, B. 1988: The Late Weichselian macrofossil flora in western Skăne, southern Sweden. LUNDQUA Thesis 24, 1-82.

Ringberg, B. 1991: Late Weichselian clay varve chronology and glaciolacustrine environment during deglaciation in southeastern Sweden. Sveriges Geologiska Undersökning 79, 1-42.

Strömberg, B. 1994: Younger Dryas deglaciation at Mt. Billingen, and clay varve dating of the Younger Dryas/Preboreal transition. Boreas 23, 177-193.

Stuiver, M. \& Reimer, P. 1993: Extended ${ }^{14} \mathrm{C}$ data base and revised CALIB $3.0^{14} \mathrm{C}$ age calibration program. Radiocarbon $35 / I, 215-$ 230.

Wohlfarth, B. 1996: The chronology of the Last Termination: a review of high-resolution terrestrial stratigraphies. Quaternary Science Revien's 15, 267-284.

Wohlfarth, B., Björck, S., Lemdahl, G. \& Ising, J. 1994: Ice recession and depositional environment in the Blekinge archipelago of the Baltic Ice Lake. GFF 116, 3-12.

Wohlfarth, B., Björck, S. \& Possnert, G. 1995: The Swedish Time Scale - a potential calibration tool for the radiocarbon time scale during the Late Weichselian. Radiocarbon 37, 347-360.

Wohlfarth, B., Björck, S., Possnert, G.. Lemdahl, G., Brunnberg, L., Ising, J., Olsson, S. \& Svensson, N.-O. 1993: AMS dating Swedish varved clays of the last glacial/interglacial transition and the potential/difficulties of calibrating Late Weichselian 'absolute' chronologies. Boreas 22, 113-128.

Wohlfarth, B., Possnert, G., Skog, G. \& Holmquist, B. 1998 Pitfalls in AMS radiocarbon-dating of terrestrial macrofossils. Journal of Quaternary Science 13, 137-145.

Wohlfarth, B.. Björck, S., Cato, I. \& Possnert, G. 1997: A new middle Holocene varve diagram from river Ångermanälven, Northern Sweden: indications for a possible error in the Holocene varve chronology. Boreas 4, 347-354. 